Economic and Environmental Geology

Research Paper

\title{
Genetic Environments of Dongwon Au-Ag-bearing Hydrothermal Vein Deposit
}

\author{
Sunjin Lee, Sang-Hoon Choi ${ }^{*}$ \\ Department of Earth and Environmental Sciences, Chungbuk National University, Cheongju 28644, Korea \\ *Corresponding author : cshoon@cbnu.ac.kr
}

\section{ARTICLE INFORMATION}

Manuscript received 19 December 2021

Received in revised form 22 December 2021

Manuscript accepted 22 December 2021

Available online 28 December 2021

DOI : http://dx.doi.org/10.9719/EEG.2021.54.6.753

\section{Research Highlights}

- The Dongwon hydrothermal Au-Ag deposit is located within the Paleozoic Taebaeksan province, Okcheon belt.

- The hydrothermal system formed by fluid boiling, cooling and dilution via influx of cooler, more dilute meteoric waters.

- The deposit may represents a Korean-type and/or Au-Ag type mesothermal/epithermal gold-silver deposit.

\begin{abstract}
The Dongwon Au-Ag deposit is located within the Paleozoic Taebaeksan province, Okcheon belt. Mineral paragenesis can be divided into two stages (stage I, ore-bearing quartz veins; stage II, barren carbonate veins) by major tectonic fracturing. Stage I, at which the precipitation of major ore minerals occurred, is further divided into three substages(early, middle and late) with paragenetic time based on minor fractures and discernible mineral assemblages: early, marked by deposition of pyrite with minor magnetite, pyrrhotite and arsenopyrite; middle, characterized by introduction of electrum and base-metal sulfides with minor sulfosalts; late, marked by argentite, $\mathrm{Cu}-\mathrm{As}$ (and/or $\mathrm{Sb}$ ) and Ag-Sb sulfosalts with base-metal sulfides. Fluid inclusion data show that stage I ore mineralization was deposited between initial high temperatures $\left(\geq 430^{\circ} \mathrm{C}\right)$ and later lower temperatures $\left(\leq 230^{\circ} \mathrm{C}\right)$ from fluids with salinities between 6.0 to 0.4 wt. percent equiv. $\mathrm{NaCl}$. The relationship of salinity and homogenization temperature suggest that ore mineralization at Dongwon was deposited mainly due to fluid boiling, cooling and dilution via influx of cooler, more dilute meteoric waters. Changes in stage I vein mineralogy reflect decreasing temperature and fugacity of sulfur by evolution of the Dongwon hydrothermal system with increasing paragenetic time. The Dongwon deposit may represents a Korean-type and/or Au-Ag type mesothermal/epithermal goldsilver deposit.
\end{abstract}

Keywords : Dongwon Au-Ag deposit, hydrothermal, fluid inclusion, vein deposit

Citation: Lee, S., Choi, S.-H. (2021) Genetic Environments of Dongwon Au-Ag-bearing Hydrothermal Vein Deposit. Korea Economic and Environmental Geology, v.54, p.753-765, doi:10.9719/EEG2021.54.6.753.

This is an Open Access article distributed under the terms of the Creative Commons Attribution Non-Commercial License (http://creativecommons.org/ licenses/by-nc/3.0) which permits unrestricted non-commercial use, distribution, and reproduction in any medium, provided original work is properly cited. pISSN 1225-7281; eISSN 2288-7962/C2021 The KSEEG. Printed by Hanrimwon Publishing Company. All rights reserved. 


\section{연구논문}

\section{동원 함 금은 열수 맥상광상의 생성환경}

이선진 · 최상훈*

충북대학교 지구환경과학과

*책임저자 : cshoon@cbnu.ac.kr

\section{요 약}

동원광상은 옥천대 북서부 태백산분지 내에 분포하는 조선누층군의 변성암류, 퇴적암류 또는 화성암류 내에 발달된 열극을 충 진하여 생성된 함 금-은 열수맥상 광상으로, 괴상 및 각력상 조직과 함께 정동의 발달 등 복합적인 조직적 특성을 보여준다. 동 원광상의 맥상 광화작용은 지구조적 운동(tectonic break)에 의하여 광화 1시기(stage I)와 광화 2시기(stage II)로 구분된다. 광화 1 시기는 석영맥의 생성과 함께 주된 함 금-은 광물인 에렉트럼(electrum)과 함께 황화광물, 산화광물 및 황염광물 등이 산출한 시기로서, 공생관계와 광물 조합 특성 등에 의하여 세 단계의 광화시기(초기, 중기, 후기)로 구분된다. 광화 1 시기의 초기에는 주로 황철석, 자철석, 자류철석, 유비철석 등이 산출되었다. 중기에는 주된 금-은 광화작용이 진행되어 에렉트럼과 함께 섬아연 석, 황동석, 방연석 등의 황화광물과 함 은 광물 및 황염광물 등이 산출되었다. 후기에는 황철석, 섬아연석, 방연석 등과 함께 함 은.안티몬 광물 등이 산출되었다. 광화 2 시기는 주 광화작용 이후의 금속 광화작용이 이루어지지 않은 방해석과 백운석맥의 생 성시기이다. 동원광상 광화작용은 초기 고온 $\left(\geq 430^{\circ} \mathrm{C}\right)$ 의 열수유체 유입으로 시작되어 냉각과 비등작용 및 상대적으로 천부를 순환한 열수유체 또는 천수의 혼입 등에 의하여 $\geq 430^{\circ} \mathrm{C} \sim 230^{\circ} \mathrm{C}$ 의 온도조건에서 6.0 to 0.4 wt. percent $\mathrm{NaCl}$ 상당 염농도를 갖는 유체에서 진행되었다. 동원광상의 광물 공생관계 변화는 이러한 열수계의 진화에 의한 온도와 황 분압 조건의 감소 등의 환경변화가 반영된 결과이다. 동원광상은 한국형 금-은 광상 및 금-은 혼합형 광상에 해당하는 중/천열수 광상에 대비된다.

주요어 : 동원 금-은 광상, 열수, 유체포유물, 맥상광상

\section{1. 서 론}

금은 예로부터 통화 결제 수단으로서 화폐금속의 역할 과 장신구 등의 제작에 사용하는 등 부의 상징으로서 그 수요가 있었으며, 최근에는 물리적 특성을 활용하여 전 자산업, 생물학적 연구 등 첨단산업 분야에서의 활용 등 에 의하여 그 수요가 꾸준히 증가하고 있어 함 금-은 광 물자원의 탐사-개발의 필요성이 강조되고 있다.

국내에 부존하는 금·은 광상은 한반도 전역에 걸쳐 수 백여 개의 광상이 광범위하게 분포하고 있다. 이들 금·은 광상들은 성인적으로 열수 맥상광상, 열수 교대광상, 스 카른광상, 알라스카이트광상 및 퇴적광상인 사금광상 등 의 유형으로 분류되지만, 국내 중요한 금·은 광상들의 대 부분은 열수 맥상광상에 속한다.

동원광상은 함 금-은 맥상광상으로 가산금맥, 가산은맥, 장곡갱맥, 제동맥, 남창갱맥 및 한치남부맥 등으로 구성 된다. 동원광산은, 1969년에 임계 110 및 120호에 위치 하는 광곡갱맥과 절골맥, 호명 101 및 111호에 위치하는 가산금맥, 가산은맥, 장곡갱맥에 대하여 굴진 조사를 진 행하였으며, 1975년에는 매장량 조사가 이루어졌다. 이 후 1982 년에 광곡갱맥과 절골맥에 대한 기본조사를 진행
하였으며, 1982년에는 동원그룹이 광업권을 인수하여 광 산개발을 재개하였다. 동원광산은 재개발 착수 후 매년 매장량 및 시추조사가 진행되었으며, 1991년과 2020년에 는 광업진흥공사에서 호명 $101,111,112$ 호 등 해당 지역 에 대한 금-은광 정밀조사를 진행하였다. 함 금-은 동원 광상의 품위는 $\mathrm{Au}: \operatorname{Tr} 11.1 \mathrm{~g} / \mathrm{t}, \mathrm{Ag}: \operatorname{Tr} 122 \mathrm{~g} / \mathrm{t}$ 으로 각 맥 상 광체 별로 차이를 보여준다(한국광물자원공사, 2020).

본 연구는 동원광상의 맥상광체 중 항내 입항이 가능 했던 장곡갱맥, 제동맥 및 한치남부맥에 대하여 개설된 갱도에 대한 현장 조사와 채취한 시료를 대상으로 실험연구를 수행하여, 함 금-은 열수 맥상광상의 광화작용과 관련된 광석광물의 산출상태, 광물학적 특성, 광물 공생 관계, 열역학적 자료에 근거한 광석광물의 침전환경 및 광화유체의 특성과 진화과정 등을 밝히고, 이를 근거로 광상 생성 시의 지배적인 물리·화학적 요인과 부존 특성 등을 규명하여 추가 탐사 및 재개발 등에 활용 가능한 광상학적 지침자료를 제시하고자 한다.

\section{2. 지질개요}

동원광상은 한반도 지체구조 상으로 옥천대 북서부에 


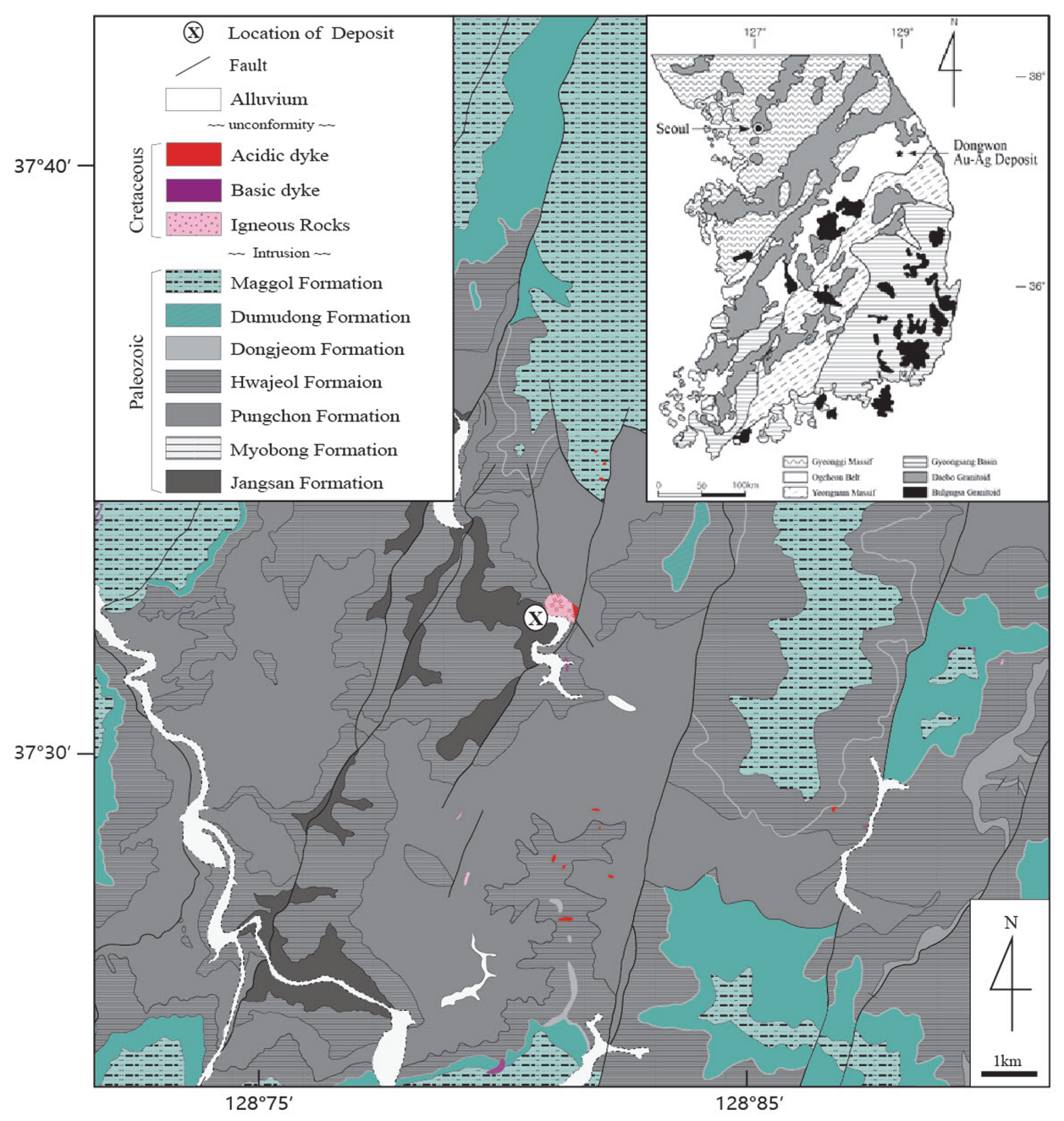

Fig. 1. Geological map of the Dongwon deposit (from KIGAM, 1962a, b, c and d) with simplified geologic map of Korea showing the tectonic province and location of the Dongwon deposit.

위치한다(Figure 1). 옥천대는, 선캠브리아 변성복합체를 기반암으로 하는 경기육괴와 영남육괴를 경계로 하며, 주 로 퇴적암류가 분포하는 비변성대인 태백산분지(옥천대 의 북동부)와 퇴적기원 변성암이 분포하는 옥천변성대(옥 천대의 남서부)로 구분된다(대한지질학회, 1999). 동원광 상은 옥천대 태백산분지 내의 태백산 광화대에 위치하며, 고생대 변성암류 및 퇴적암류로 구성된 조선누층군과 이 들을 후기에 관입하는 쥬라기 대보 화성암체 및 주로 암 주상 또는 암맥상으로 산출하는 백악기 불국사 화성암체 가 분포한다. 조선누층군은 기반암인 선캠브리아기 변성 암류를 부정합으로 피복 하여, 하부로부터 고생대 장산 층, 묘봉층, 풍촌층, 화절층, 동점층, 두무동층 및 막골층 으로 이루어져 있다. 묘봉층 및 풍촌층의 화성암류 접촉 부 일대는 부분적으로 혼펠스화 또는 스카른화 되어 있 다(Park and Park, 1990).
동원광상 일대 지질은 상기 고생대 조선누층군(장산층, 묘봉층, 풍촌층, 화절층, 두무동층 및 막골층)의 변성암류 와 퇴적암류로 구성되어 있으며, 이들을 관입하여 산출 하는 백악기 화강암류와 염기성 또는 산성 암맥류가 분 포한다(Figure 1).

장산층은, 조선누층군의 최하부 층으로 동원광산과 바 로 인접하여 위치하며, 광상지역 중심부로부터 남부 일 대에 산출 분포한다. 장산층은 40 200m 층후를 가지며 유백색 또는 담홍색으로 관찰되며, 하부로부터 기저역암, 규암 및 함 력 석회암으로 구분된다. 이러한 장산층의 형 성은 대륙붕 연변의 천해 퇴적환경에서 이루어진 것으로 추정하여 보고된 바 있다(손치무와 정창희, 1965).

묘봉층은 장산층 상부에 정합관계를 보여주며 산출하 고 있으며, 80 250m의 층후를 보여준다. 주로 암회색 또 는 암녹색 셰일 또는 슬레이트로 구성되어 있다. 묘봉층 

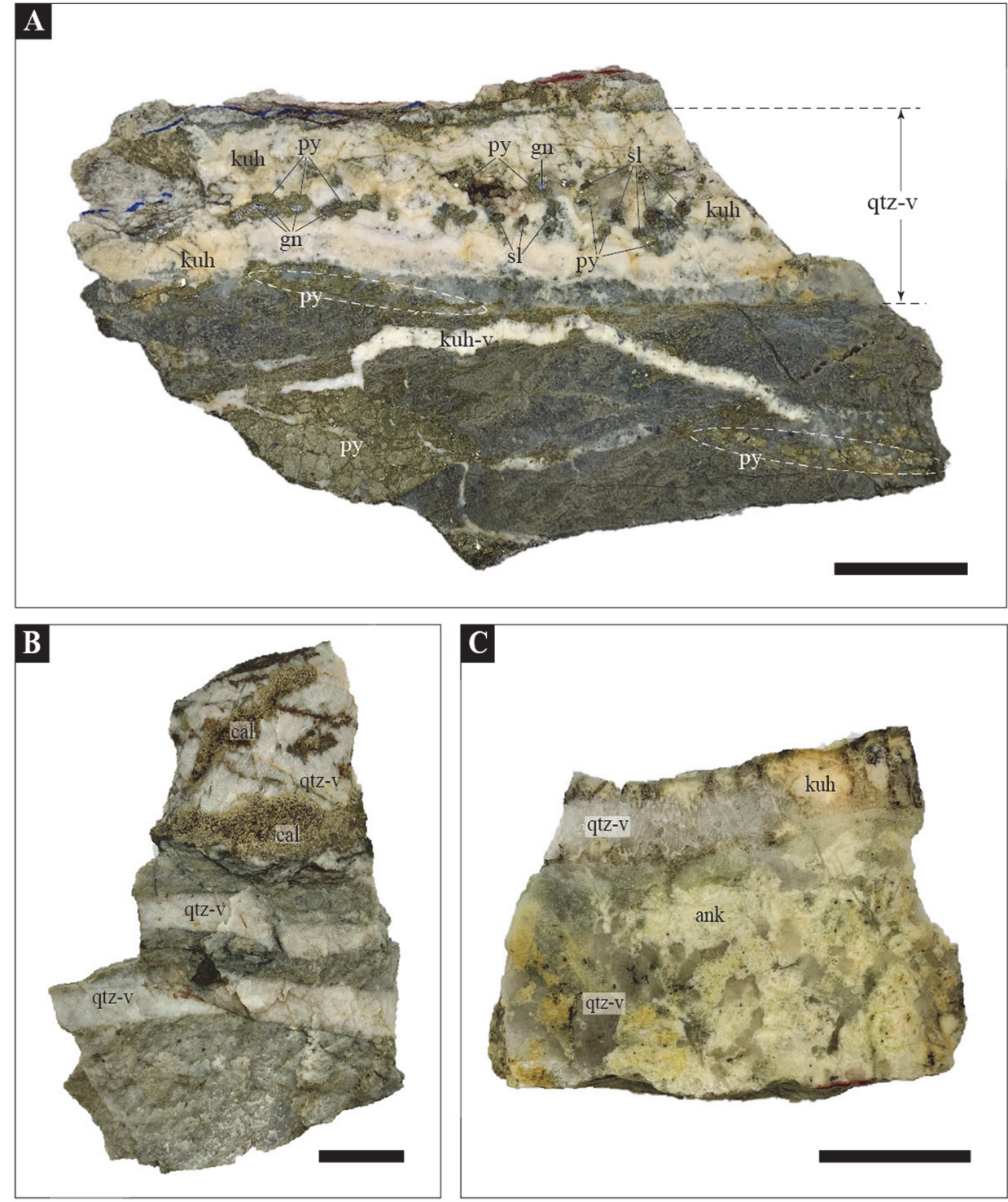

Fig. 2. Photographs of the products of hydrothermal mineralization at Dongwon deposit. Scale bar is $3 \mathrm{~cm}$. Abbreviations: ank=ankerite, cal=calcite, gn=galena, kuh=kutnohorite, py=pyrite, qtz=quartz, sl=sphalerite, $v=$ vein.

의 상부층에서는 얇은 사암층이나 석회암층이 협재 하여 산출하며, 하부층은 암회색 슬레이트층이다. 동원광산 지 역 내에서 확인되는 묘봉층은 주로 셰일 또는 슬레이트 로 구성되어 있으며, 지역 서남부에서 남북방향으로 산 출한다.

풍촌층은 묘봉층을 정합으로 피복하여 산출하며, 주로 유백색, 암회색 등의 탄산염암으로 구성되며, 각 암상 간 에 돌로마이트질 석회암이 협재 되어 산출한다. 동원광 상 주변 전역에 넓게 분포한다(Figure 1).

화절층은 퇴적환경의 주기적인 변화를 반영하여 석회 암 및 셰일층 등이 교호하는 층상구조를 보이며 산출한 다. 화절층은 풍촌층과 인접하여 동원광상 주변 전역에
분포한다(Figure 2).

두무동층은, 층후 150 270m로, 석회암 또는 돌로마이 트와 셰일층 등이 교호하여 산출한다. 동원광상 지역에 서 두무동층은 상기 하부 조선누층군의 암층들을 피복하 여 외곽부에 분포한다.

막골층은 두무동층을 정합으로 피복 하여 산출하며, 석 회질 이암, 돌로마이트 등으로 구성된 탄산염암 층으로 동원광상 지역 북쪽과 동쪽 및 남익부에 분포한다(Figure 1).

동원광상 일대에서 장산층, 풍촌층 및 묘봉층 등을 관 입 산출하는 화성암류는 주로 석영 섬록암, 석영 몬조나 이트, 반상화강암 및 화강섬록암 등으로 구성되며(박희인 과 박영록, 1990), 중생대 백악기 염기성 또는 산성의 암 
맥들이 북북동의 방향성을 보이며 동원광상 인근 및 남 부에 소규모로 산출 분포한다.

\section{3. 광 상}

동원광상은 조선누층군의 장산층, 묘봉층 및 풍촌층의 변성암류, 퇴적암류 또는 화성암류 내에 발달된 열극을 충진 하여 생성된 함 금-은 열수 맥상광상이다. 동원광상 은 광곡갱맥, 절골맥, 가산(금, 은)맥, 장곡맥, 제동맥, 남 창갱맥 및 한치남부맥 등 주된 7개 조의 함 금-은 열수 석영맥으로 구성되어 있다. 동원광상을 구성하는 주요 광 맥들의 주향 및 경사는 $\mathrm{N} 60^{\circ} \mathrm{W} / 75^{\circ} \mathrm{NE}$ (광곡갱맥, 절골맥), $\mathrm{NS} / 75^{\circ} \mathrm{E}$ (가산은맥), $\quad \mathrm{N} 25^{\circ} \mathrm{E} / 70^{\circ} \mathrm{NE}$ (가산금맥), $\mathrm{N} 10^{\circ} \mathrm{E} /$ $75^{\circ} \mathrm{NW}$ 내지 $\mathrm{N} 20^{\circ} \mathrm{W} / 75^{\circ} \mathrm{SE}$ (제동맥) 및 $\mathrm{N} 30^{\circ} \mathrm{E} / 80^{\circ} \mathrm{SE}$ (남 창갱맥 및 한치남부맥) 등으로 주요 광맥별로 불규칙한 방향성을 보여준다(한국광물자원공사, 2020). 붕락된 갱 도를 제외하고 조사 당시 입항이 가능했던 제동갱, 서갱 (가산맥 부근), 한치갱에서 확인된 맥폭은 $\leq 5 \sim 30 \mathrm{~cm}$ 로 확 인되었다. 광맥들은 과거 연맥 굴진을 진행하였으나, 갱 도 붕락으로 확인할 수 있는 연장은 제한적이다. 제동갱, 서갱, 한치갱에서 확인된 동원광상의 함 금-은 광체는 주 로 단층작용에 의하여 발달한 열극을 열수가 충진하여 생성된 괴상의 석영맥으로 부분적으로 각력상구조 및 정 동구조 등이 발달하여 복합적인 조직적 특성을 보여주는 함 금-은 열수 맥상광체이다(Figure 2).

제동갱에서는 다양한 광석광물들이 석영맥 내에 수반 되어 산출된다. 석영맥 내에는 주로 산점상 또는 세맥상 의 황철석이 관찰되며, 부분적으로 괴상 또는 산점상 섬 아연석 및 방연석이 산출된다(Figure 2). 부분적으로 방 해석과 돌로마이트군에 해당하는 kutnohorite와 철백운석 (ankerite)이 모암과의 경계부 또는 석영맥을 절단하며 산 점상 또는 맥상으로 산출한다(Figure 2).

\section{4. 광물 및 공생관계}

동원광상의 광화작용은 지구조적 운동(tectonic break) 에 의하여 광화 1시기(stage I)와 광화 2시기(stage II)로 구분된다(Figure 3). 광화 1시기는 함 금-은 광화작용이 석영맥의 생성과 함께 진행된 주 광화시기로서, 석영맥 내 주된 함 금·은 광물인 에렉트럼(electrum)과 함께 함 금속 황화광물, 산화광물 및 황염광물 등이 산출한다. 광 화 2시기는 주 광화작용 이후의 금-은 등 금속 광화작용 이 이루어지지 않은 방해석과 백운석 맥의 생성 시기이 다(Figure 3).

광화 1 시기: 광화 1 시기는 광물 공생관계와 산출하는

\begin{tabular}{|c|c|c|c|}
\hline Minerals & Stage I & & Stage II \\
\hline Ouartz & 1 & & \\
\hline Pyrite & & & \\
\hline Pyrrhotite & & & \\
\hline Magnetite & & & \\
\hline Arsenopyrite & & & \\
\hline & & & \\
\hline Chalcopyrite & & & \\
\hline Sphalerite & & & \\
\hline Galena & & बै & \\
\hline Electrum & & 0 & \\
\hline Argentite & & ": & \\
\hline Tennantite & $--\cdot$ & 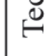 & \\
\hline Polybasite & 工 & & \\
\hline Tetrahedrite & & & \\
\hline Stephanite & 1 & & \\
\hline Pyrargyrite & & & \\
\hline Calcite & 1 & & \\
\hline Ankerite & & & \\
\hline Kutnohorite & 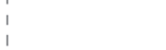 & & \\
\hline
\end{tabular}

Fig. 3. Mineral paragenesis of the Dongwon $\mathrm{Au}-\mathrm{Ag}$ deposit.

광물 조합 특성 등에 의하여 세 단계의 광화시기(초기, 중기, 후기)로 구분된다(Figure 3). 동원광상 열수 석영 맥 상광체(광화 1 시기)의 광화작용 초기에는 함 철 황화광 물 및 산화광물이 우세하게 산출하는 시기로서, 주로 황 철석(pyrite), 자철석(magnetite), 자류철석(pyrrhotite), 유 비철석(arsenopyrite) 등이 산출되었다. 광화 1시기 중기 에는 주된 금-은 광화작용이 진행되어 에렉트럼(electrum) 과 함께 섬아연석(sphalerite), 황동석(chalcopyrite), 방연 석(galena)을 비롯한 황화광물과 주요 함 은 광물인 휘은 석(argentite), 비소(As) 및 안티몬(Sb) 황염광물인 텐난타 이트(tennantite), 폴리바사이트(polybasite) 및 테트라헤드 라이트(tetrahedrite) 등이 산출되었다. 광화 1 시기 후기 광 화작용 시기에는 주로 후기에 산출된 황철석, 섬아연석, 방연석 등과 함께 함 은.안티몬 광물인 취은석(stephanite), 농홍은석(pyrargyrite) 등이 산출되었다(Figure 3).

황철석은 주로 초기 생성된 석영맥을 따라 산점상 및 세립의 자형으로 산출하거나 조립상의 자형 및 반자형의 입자들이 모여 괴상 형태로 산출된다(Figure 4). 광화 1 시기 초기 광화작용 동안 생성된 괴상의 황철석은 부분 적으로 유비철석과 밀접한 공생관계를 이루며 산출된다. 중기 황철석은 산점상 내지 세립의 형태로 부분적으로 황동석과 함께 섬아연석의 내부 균열부를 충진하여 산출된다. 

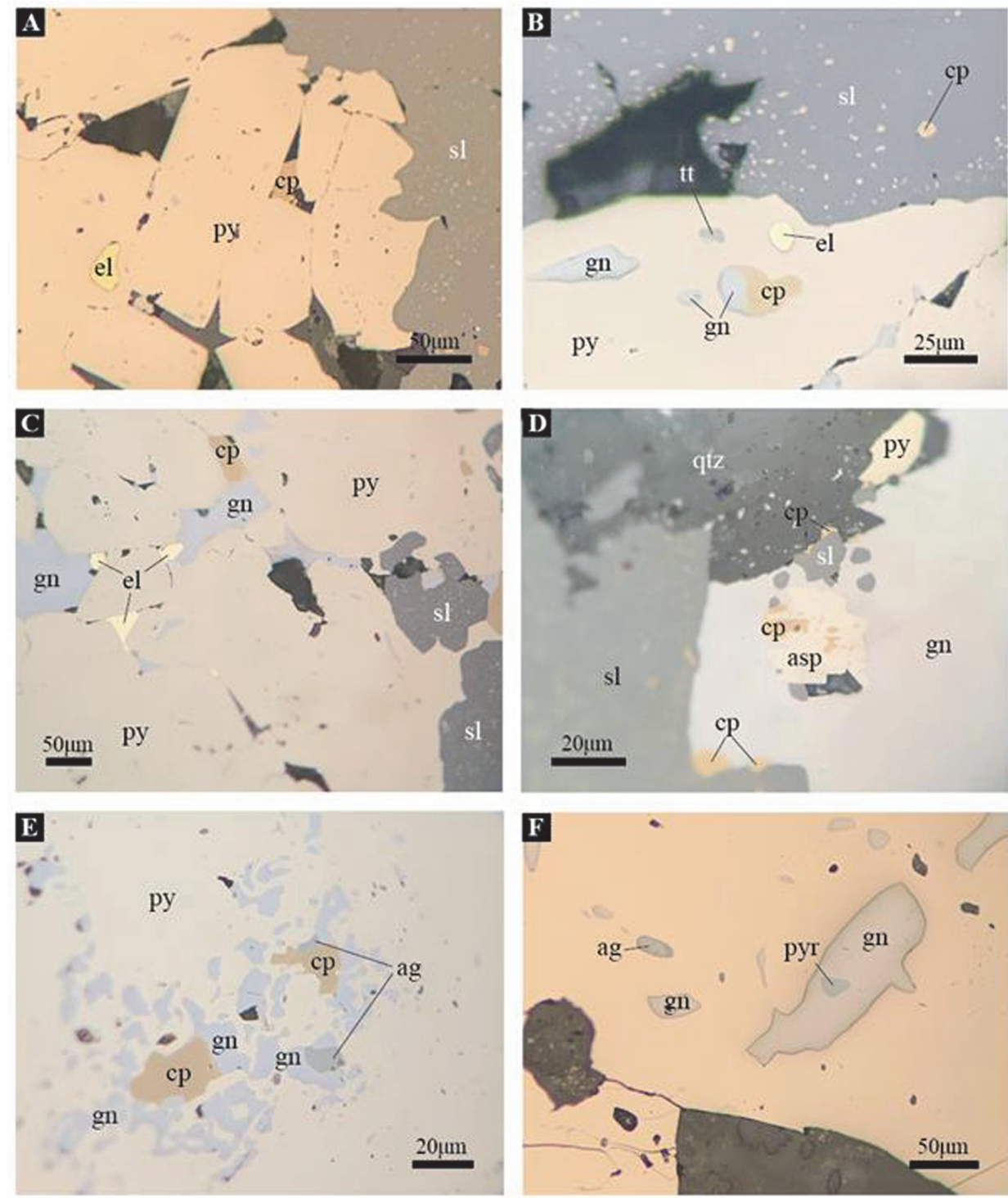

Fig. 4. Photomicrographs of mineral occurrence and assemblages at the Dongwon deposit. Abbreviations: ag=argentite, asp=arsenopyrite, $\mathrm{cp}=$ chalcopyrite, $\mathrm{el}=$ electrum, $\mathrm{gn}=$ galena, $\mathrm{py}=$ pyrite, $\mathrm{pyr}=$ pyrargyrite, $\mathrm{qtz}=$ quartz, $\mathrm{sl}=$ sphalerite, $\mathrm{tt}=\mathrm{tetrahedrite}$.

자류철석은 초기 황철석 내부에 포획되거나 균열부를 충진하여 산출한다. 일부 자류철석은 황동석에 의하여 교 대된 형태로 관찰된다.

함 철 산화광물인 자철석은 맥상 석영 및 초기 괴상의 황철석 내에 자형 내지 반자형으로 산출하거나, 자형의 황철석에 생성된 방사형의 내부 균열부를 충진하거나 교 대하여 산출한다.

유비철석은 주로 초기 황철석 내에 포획되어 산출하거 나 괴상의 황철석 내부 균열부를 따라 교대하여 산출하 며, 부분적으로 광화 1기 중기 광화작용 시기 동안 산출 된 방연석 내부에 포획되어 산출되기도 한다(Figure 4D). 전자현미분석(EPMA) 결과 확인된 이들 유비철석의 조
성은 25.8 31.4 atomic \% As의 조성을 보여준다(Table 1).

황동석은 주로 자형의 황철석을 교대하여 괴상으로 산 출하거나 황철석의 균열부를 충진하여 산출되며, 부분적 으로 유비철석 내 균열부를 교대하여 산출한다(Figure 4). 섬아연석은 주로 광화 1 시기의 중기 광화작용 동안 침 전하였으며, 괴상의 황철석을 교대하여 괴상 또는 세맥 상으로 산출한다. 후기 광화작용의 섬아연석은 황동석의 내부 균열부를 따라 산출하거나 방연석 내 틈을 따라 산 출되기도 한다(Figure 4). 전자현미분석 결과, 섬아연석은 초기 광화작용에서 후기로 갈수록 $\mathrm{FeS}$ 함량이 감소(8.5 to $0.0 \mathrm{~mole} \% \mathrm{FeS}$ )하는 경향성을 보여준다(Table 2).

방연석은 동원광상의 광화 1 시기 초기의 말기부터 후 
Table 1. Chemical composition of arsenopyrite from Dongwon deposit

\begin{tabular}{|c|c|c|c|c|c|c|c|c|}
\hline \multirow{2}{*}{ sample no. } & \multicolumn{4}{|c|}{ weight percent } & \multicolumn{4}{|c|}{ atomic $\%$} \\
\hline & $\mathrm{Fe}$ & As & $\mathrm{S}$ & Total & $\mathrm{Fe}$ & As & $\mathrm{S}$ & Total \\
\hline c2-1-2-1 & 38.0 & 40.2 & 21.8 & 100.0 & 35.8 & 28.4 & 35.8 & 100.0 \\
\hline c2-1-3-1 & 37.0 & 38.4 & 24.6 & 100.0 & 34.0 & 26.3 & 39.7 & 100.0 \\
\hline c2-1-3-3 & 37.8 & 40.6 & 21.6 & 100.0 & 36.0 & 28.6 & 35.5 & 100.0 \\
\hline c2-1-6-1 & 35.8 & 43.6 & 20.6 & 100.0 & 34.4 & 31.2 & 34.4 & 100.0 \\
\hline c2-1-7 & 36.7 & 43.8 & 19.5 & 100.0 & 35.7 & 31.4 & 33.0 & 100.0 \\
\hline c2-1-8 & 37.3 & 43.0 & 19.7 & 100.0 & 36.0 & 30.7 & 33.3 & 100.0 \\
\hline c2-1-13 & 37.7 & 41.1 & 21.2 & 100.0 & 36.0 & 29.1 & 34.9 & 100.0 \\
\hline $31-10-7-1$ & 37.1 & 41.0 & 21.9 & 100.0 & 34.9 & 29.1 & 36.0 & 100.0 \\
\hline $31-7-2-1$ & 39.3 & 37.5 & 23.2 & 100.0 & 36.5 & 26.0 & 37.5 & 100.0 \\
\hline $31-7-3-1$ & 36.8 & 42.0 & 21.2 & 100.0 & 35.1 & 29.8 & 35.1 & 100.0 \\
\hline $31-7-4-1$ & 38.3 & 40.0 & 21.6 & 100.0 & 36.3 & 27.9 & 35.8 & 100.0 \\
\hline $31-8-2-1$ & 36.6 & 40.2 & 23.3 & 100.0 & 33.9 & 28.1 & 38.0 & 100.0 \\
\hline $31-8-3-1$ & 38.7 & 37.3 & 24.0 & 100.0 & 35.6 & 25.8 & 38.7 & 100.0 \\
\hline $31-8-6-1$ & 35.1 & 43.1 & 21.9 & 100.0 & 33.5 & 30.3 & 36.2 & 100.0 \\
\hline $31-8-7-1$ & 38.5 & 39.1 & 22.3 & 100.0 & 36.1 & 27.2 & 36.7 & 100.0 \\
\hline $31-3-1-1$ & 39.4 & 38.0 & 22.6 & 100.0 & 36.5 & 26.6 & 37.0 & 100.0 \\
\hline $31-3-2-1$ & 39.2 & 37.5 & 23.2 & 100.0 & 36.3 & 25.9 & 37.8 & 100.0 \\
\hline DD32-7-1 & 36.8 & 39.7 & 23.5 & 100.0 & 34.4 & 27.6 & 38.0 & 100.0 \\
\hline
\end{tabular}

기까지 산출되었다. 초기 방연석의 경우 주로 괴상의 황 철석을 교대하여 산출한다. 일부 방연석은 황동석과 황 철석의 균열부를 충진하여 산출되며, 부분적으로 유비철 석과 에렉트럼을 포획하여 산출한다(Figure 4).

동원광상의 주된 함 금-은 광물인 에렉트럼은 광화 1 시기 초기의 말기부터 광화 1 시기 중기에 걸쳐 침전이 이루어진 것으로 확인된다. 에렉트럼은 주로 괴상의 황 철석 내부에 포획되거나 균열부를 충진하여 산출한다 (Figure 4). 전자현미분석 결과, 광화 1시기 에렉트럼의 화학조성 변화는 초기(최대; $\leq 72.7$ atomic $\% \mathrm{Au}$ ) 및 중 기(최소; $\geq 43.5$ atomic \% Au) 등 광화 1 시기의 세분된 광화시기에 따라 상이했으며, 광화작용이 진행됨에 따라 $\mathrm{Au}$ 의 함량은 감소하는 것으로 확인되었다(Table 3).

동원광상의 광화 1 시기의 중기에는 함 은.안티몬 광물 혹은 함 은·비소·안티몬 황염광물 등의 광화작용이 시작 되어 광화 1 시기의 후기까지 진행되었다(Figures $4 \mathrm{E}$ and $4 \mathrm{~F})$. 주된 함 은 광물인 휘은석은 초기 괴상의 황철석 균 열부를 따라 산출되거나 에렉트럼을 포획하여 산출된다. 광화작용 후기에 이르면서 휘은석은 황동석을 교대하거 나 방연석 또는 황동석의 균열부를 충진하여 산출한다. 폴리바사이트는 휘은석을 일부 교대하거나 황동석의 균 열부를 충진하여 산출한다. 테트라헤드라이트는 주로 괴 상의 방연석 균열부를 충진 또는 교대하여 산출하거나
황동석 균열부를 충진 또는 일부 교대하여 산출한다. 취 은석은 방연석의 내부 균열부를 세립으로 충진하거나 방 연석과 섬아연석의 경계부를 따라 교대하여 산출된다. 농 홍은석은 동원광상 열수 맥상광체 광화 1 시기 광화작용 후기에 주로 산출 되었으며, 방연석의 내부 균열부를 충 진하여 산출한다(Figure $4 \mathrm{~F}$ ).

광화 2시기: 동원 함 금-은 열수 맥상 광상 광화 2시기 는 주 광화작용이 진행된 이후의 금-은 및 금속 광화작 용이 이루어지지 않은 시기로서, 부분적으로 백운석을 포 함하는 방해석맥의 생성 시기이다. 광상 내 부분적으로 생성 관찰되는 광화 2시기 방해석맥은 주 광화작용이 진 행된 광화 1 시기 석영맥을 절단하거나, 석영맥 내에 발 달한 소규모 균열면을 충진하여 산출한다(Figure 2).

\section{5. 유체포유물}

유체포유물 실험·연구는 동원광상 열수 맥상광체 내 광 화 1 시기 석영 시료를 대상으로 양면 연마박편을 제작하 여 유체포유물에 대한 가열·냉각 실험을 수행하였다. 현 미경 가열·냉각 실험은 충북대학교 광상학 실험실에 설 치된 Linkam scientific Instruments의 THMS 600(TMS 93) Heating/Freezing stage를 이용하여 수행되었다. 유체포유 물에 대한 가열·냉각 실험 시에는 정확도를 높이기 위해 
Table 2. Chemical composition of sphalerite from Dongwon deposit

\begin{tabular}{|c|c|c|c|c|c|c|c|c|c|c|c|}
\hline \multirow{2}{*}{ sample no. } & \multicolumn{6}{|c|}{ weight $\%$} & \multicolumn{5}{|c|}{ mole $\%$} \\
\hline & $\mathrm{Zn}$ & $\mathrm{Fe}$ & $\mathrm{Mn}$ & $\mathrm{Cd}$ & $S$ & Total & $\mathrm{ZnS}$ & $\mathrm{FeS}$ & $\mathrm{MnS}$ & $\mathrm{CdS}$ & Total \\
\hline c2-1-8-3 & 61.7 & 2.3 & 0.5 & 1.5 & 34.6 & 100.5 & 93.7 & 4.1 & 0.9 & 1.3 & 100.0 \\
\hline c2-1-8-4 & 61.4 & 2.4 & 0.4 & 0.0 & 34.4 & 98.6 & 95.0 & 4.3 & 0.7 & 0.0 & 100.0 \\
\hline $31-10-3-1$ & 61.7 & 2.9 & 0.7 & 0.0 & 34.8 & 100.0 & 93.7 & 5.1 & 1.2 & 0.0 & 100.0 \\
\hline $31-10-4-1$ & 61.2 & 3.0 & 0.4 & 0.0 & 35.5 & 100.0 & 94.0 & 5.4 & 0.7 & 0.0 & 100.0 \\
\hline $31-10-5-1$ & 58.5 & 4.4 & 0.7 & 0.0 & 34.5 & 98.1 & 90.7 & 8.0 & 1.3 & 0.0 & 100.0 \\
\hline $31-10-6-1$ & 63.2 & 2.1 & 0.5 & 0.0 & 34.2 & 100.0 & 95.5 & 3.7 & 0.8 & 0.0 & 100.0 \\
\hline $31-9-2-1$ & 61.1 & 3.5 & 0.3 & 0.0 & 35.2 & 100.0 & 93.3 & 6.2 & 0.5 & 0.0 & 100.0 \\
\hline $31-9-3-1$ & 63.5 & 2.4 & 0.4 & 0.0 & 33.7 & 100.0 & 95.1 & 4.2 & 0.7 & 0.0 & 100.0 \\
\hline $31-9-4-1$ & 64.1 & 2.8 & 0.5 & 0.0 & 32.6 & 100.0 & 94.3 & 4.8 & 0.9 & 0.0 & 100.0 \\
\hline $31-9-5-1$ & 63.7 & 2.8 & 0.4 & 0.0 & 33.1 & 100.0 & 94.4 & 4.9 & 0.8 & 0.0 & 100.0 \\
\hline $31-11-2-1$ & 60.7 & 2.7 & 0.8 & 0.0 & 35.8 & 100.0 & 93.7 & 4.9 & 1.4 & 0.0 & 100.0 \\
\hline $31-11-3-1$ & 60.9 & 4.2 & 0.0 & 0.0 & 34.9 & 100.0 & 92.5 & 7.5 & 0.0 & 0.0 & 100.0 \\
\hline $31-11-4-1$ & 60.2 & 4.8 & 0.0 & 0.0 & 35.0 & 100.0 & 91.5 & 8.5 & 0.0 & 0.0 & 100.0 \\
\hline $31-8-4-1$ & 64.7 & 1.3 & 0.0 & 0.0 & 34.0 & 100.0 & 97.7 & 2.3 & 0.0 & 0.0 & 100.0 \\
\hline $31-8-5-1$ & 58.2 & 3.4 & 0.0 & 0.0 & 38.5 & 100.0 & 93.6 & 6.4 & 0.0 & 0.0 & 100.0 \\
\hline $31-6-1$ & 62.5 & 1.8 & 0.0 & 0.0 & 34.8 & 99.2 & 96.7 & 3.3 & 0.0 & 0.0 & 100.0 \\
\hline $31-6-3-1$ & 61.0 & 2.8 & 0.4 & 0.0 & 35.8 & 100.0 & 94.2 & 5.0 & 0.8 & 0.0 & 100.0 \\
\hline $31-3-5-1$ & 63.3 & 2.8 & 0.4 & 0.0 & 33.4 & 100.0 & 94.3 & 4.9 & 0.8 & 0.0 & 100.0 \\
\hline $31-3-6-1$ & 63.4 & 2.9 & 0.7 & 0.0 & 33.0 & 100.0 & 93.8 & 5.0 & 1.2 & 0.0 & 100.0 \\
\hline $31-3-7-1$ & 62.1 & 2.9 & 0.3 & 0.0 & 34.7 & 100.0 & 94.3 & 5.2 & 0.5 & 0.0 & 100.0 \\
\hline DD32-2-3 & 64.2 & 2.6 & 0.5 & 0.0 & 32.8 & 100.0 & 94.7 & 4.4 & 0.9 & 0.0 & 100.0 \\
\hline DD32-2-4 & 61.8 & 3.1 & 0.0 & 0.0 & 35.1 & 100.0 & 94.5 & 5.5 & 0.0 & 0.0 & 100.0 \\
\hline DD32-6-1 & 62.6 & 2.9 & 0.6 & 0.0 & 33.9 & 100.0 & 93.8 & 5.2 & 1.0 & 0.0 & 100.0 \\
\hline DD32-6-2 & 63.2 & 2.2 & 0.6 & 0.0 & 34.0 & 100.0 & 94.9 & 3.9 & 1.1 & 0.0 & 100.0 \\
\hline DD32-1-1 & 60.7 & 3.0 & 0.8 & 0.0 & 35.5 & 100.0 & 93.1 & 5.4 & 1.5 & 0.0 & 100.0 \\
\hline DD32-1-2 & 61.8 & 3.8 & 0.0 & 0.0 & 34.4 & 100.0 & 93.4 & 6.6 & 0.0 & 0.0 & 100.0 \\
\hline DD32-7-2 & 61.9 & 3.0 & 0.6 & 0.0 & 34.5 & 100.0 & 93.6 & 5.3 & 1.1 & 0.0 & 100.0 \\
\hline DD32-7-3 & 62.3 & 4.5 & 0.0 & 0.0 & 33.3 & 100.0 & 92.3 & 7.7 & 0.0 & 0.0 & 100.0 \\
\hline DJ11-3-1 & 64.7 & 0.5 & 0.0 & 0.0 & 34.8 & 100.0 & 99.1 & 0.9 & 0.0 & 0.0 & 100.0 \\
\hline DJ11-3-2 & 65.1 & 1.1 & 0.0 & 0.0 & 33.8 & 100.0 & 98.1 & 1.9 & 0.0 & 0.0 & 100.0 \\
\hline DJ11-3-3 & 64.0 & 0.0 & 0.0 & 0.0 & 36.0 & 100.0 & 100.0 & 0.0 & 0.0 & 0.0 & 100.0 \\
\hline DJ11-3-4 & 60.7 & 4.8 & 0.0 & 0.0 & 34.5 & 100.0 & 91.6 & 8.4 & 0.0 & 0.0 & 100.0 \\
\hline DJ11-3-5 & 64.4 & 1.1 & 0.0 & 0.0 & 34.5 & 100.0 & 98.0 & 2.0 & 0.0 & 0.0 & 100.0 \\
\hline DJ11-4-1 & 61.2 & 2.2 & 0.0 & 0.0 & 36.6 & 100.0 & 96.0 & 4.0 & 0.0 & 0.0 & 100.0 \\
\hline DJ11-4-2 & 62.2 & 2.1 & 0.0 & 0.0 & 35.7 & 100.0 & 96.3 & 3.7 & 0.0 & 0.0 & 100.0 \\
\hline
\end{tabular}

서 Haynes(1985)의 repeated freezing technique를 활용하 였으며, 가열실험에서 측정되는 균일화온도의 측정오차는 $\pm 1.0^{\circ} \mathrm{C}$ 이다. 염농도는 냉각실험에서 측정되는 ice-melting 온도와 $\mathrm{H}_{2} \mathrm{O}-\mathrm{NaCl}$ 계의 freezing-point depression(Potter et al., 1978)을 이용하여 구하였다. 냉각실험에서 측정되는 ice-melting 온도의 측정오차는 $\pm 0.2^{\circ} \mathrm{C}$ 이다.

\section{1. 유체포유물 가열 및 냉각실험 결과}

동원광상에서 확인되는 유체포유물은 상온 $\left(20^{\circ} \mathrm{C}\right)$ 에서 의 상(phase)관계 및 균일화 특성 등에 의하여 2 가지 유 형(type I: liqid-rich; type II: vapor-rich)의 $\mathrm{H}_{2} \mathrm{O}-\mathrm{NaCl}$ 계 유 체포유물이 관찰되었다(Figure 5).

Type I 유체포유물(aqueous, liquid-rich)은 기상(vapor) 
Table 3. Chemical composition of electrum from Dongwon deposit

\begin{tabular}{ccccccccc}
\hline \multirow{2}{*}{ sample no } & \multicolumn{3}{c}{ weight $\%$} & \multicolumn{3}{c}{ atomic \% } \\
\cline { 2 - 9 } & $\mathrm{Au}$ & $\mathrm{Ag}$ & $\mathrm{Fe}$ & $\mathrm{S}$ & $\mathrm{Total}$ & $\mathrm{Au}$ & $\mathrm{Ag}$ & $\mathrm{Ag} / \mathrm{Au}$ \\
\hline $\mathrm{c} 1-1-1$ & 59.3 & 31.0 & 3.0 & 6.7 & 100.0 & 51.2 & 48.8 & 1.0 \\
$\mathrm{c} 1-1-1-1$ & 65.5 & 34.0 & 0.5 & 0.0 & 100.0 & 51.3 & 48.7 & 0.9 \\
c2-1-8-2 & 60.6 & 38.5 & 1.0 & 0.0 & 100.0 & 46.3 & 53.7 & 1.2 \\
$31-3-3-1$ & 80.1 & 19.3 & 0.6 & 0.0 & 100.0 & 63.3 & 36.7 & 0.6 \\
$31-3-4-1$ & 82.2 & 16.9 & 0.9 & 0.0 & 100.0 & 72.7 & 27.3 & 0.4 \\
$31-5-1-1$ & 72.6 & 26.5 & 1.0 & 0.0 & 100.0 & 60.0 & 40.0 & 0.7 \\
$31-5-2-1$ & 63.3 & 35.9 & 0.8 & 0.0 & 100.0 & 49.1 & 50.9 & 1.0 \\
DD32-5-1 & 71.4 & 28.1 & 0.4 & 0.0 & 100.0 & 58.2 & 41.8 & 0.7 \\
DD32-2-1 & 72.5 & 26.5 & 1.0 & 0.0 & 100.0 & 60.0 & 40.0 & 0.7 \\
DD32-2-2 & 67.8 & 31.3 & 0.9 & 0.0 & 100.0 & 54.2 & 45.8 & 0.8 \\
DD32-1-3 & 72.8 & 27.2 & 0.0 & 0.0 & 100.0 & 59.5 & 40.5 & 0.7 \\
$11-1-1-1$ & 56.5 & 43.5 & 0.0 & 0.0 & 100.0 & 41.5 & 58.5 & 1.4 \\
\hline
\end{tabular}
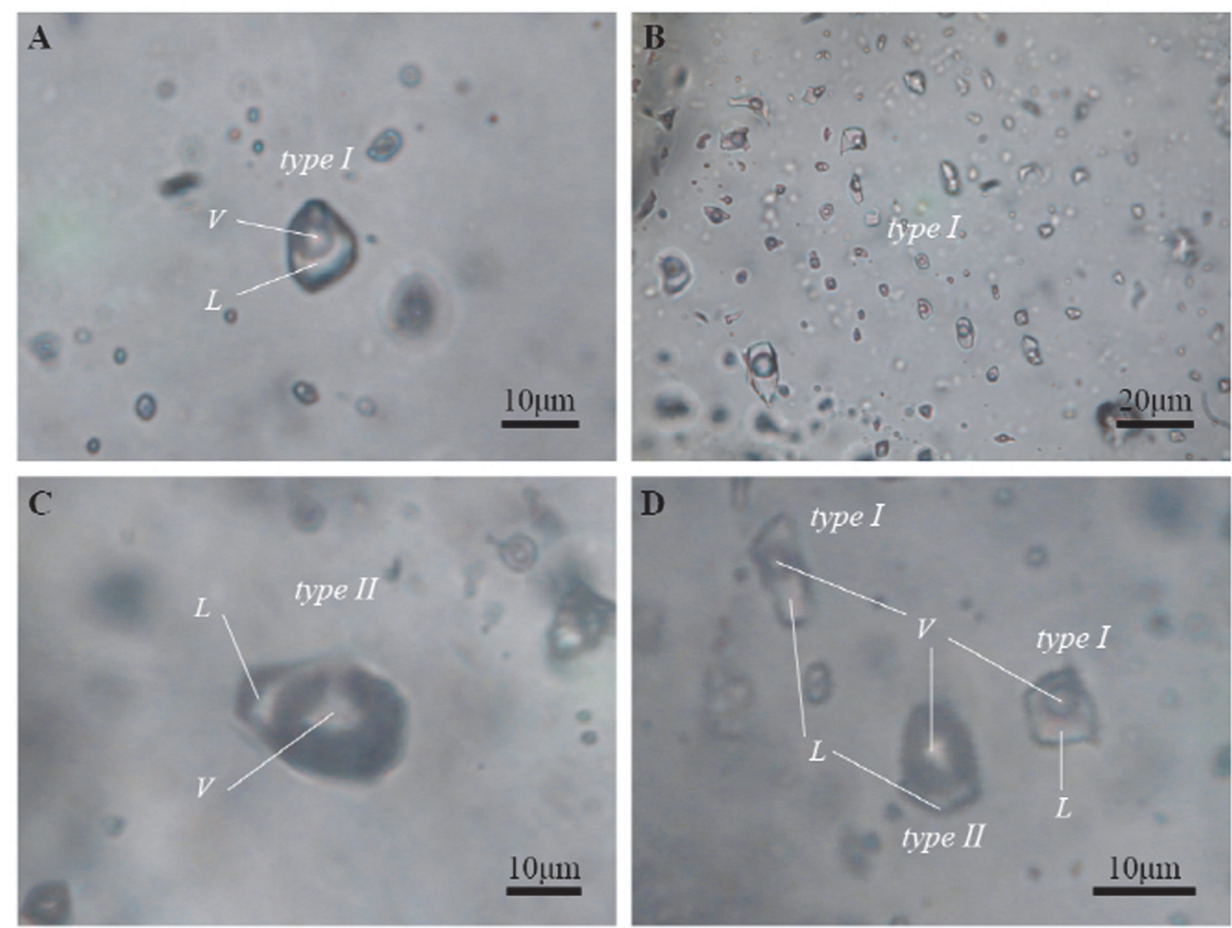

Fig. 5. Photomicrographs of type I (A, B and D) and type II (C and D) fluid inclusions in vein quartz, Dongwon deposit. Abbreviations: $V=$ vapor phase, $L=$ liquid phase, type $I=$ type I fluid inclusion, type $I I=$ type II fluid inclusion.

과 액상(aqueous liquid)으로 구성되며, 액상이 우세(약 60 vol. \% 이상)하여 가열실험 시 액상으로 균일화되는 특 징을 갖는다.

Type II 유체포유물(aqueous, vapor-rich)은 type I 유 체포유물과 같이 기상과 액상으로만 구성되나, 기상이 우 세(약 $60 \mathrm{vol} \%$ 이상)하여 가열실험 시 기상으로 균일화 되는 특징을 보여준다.
동원광상 함 금·은 열수 맥상 석영 시료의 유체포유물 에 대한 가열·냉각 실험 결과는 Figures 6 8에 제시되어 있다.

동원광상의 광화1시기 광화작용 관련 맥상 석영 시료 내 초생 유체포유물(primary fluid inclusions)은 $431^{\circ} \mathrm{C} ~ 232^{\circ} \mathrm{C}$ 의 온도 범위에서 균일화된다. 초생 유체포유물 중 type I 유체포유물은 $375^{\circ} \mathrm{C} 232^{\circ} \mathrm{C}$ 의 온도 범위에서, type II 유 


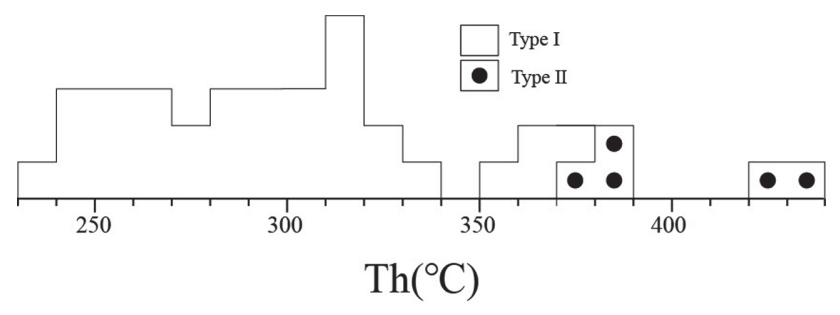

Fig. 6. Histogram of homogenization temperatures(Th) of fluid inclusions in vein quartz of the Dongwon deposit. Abbreviations: Type I=type I fluid inclusion, Type II=type II fluid inclusion.

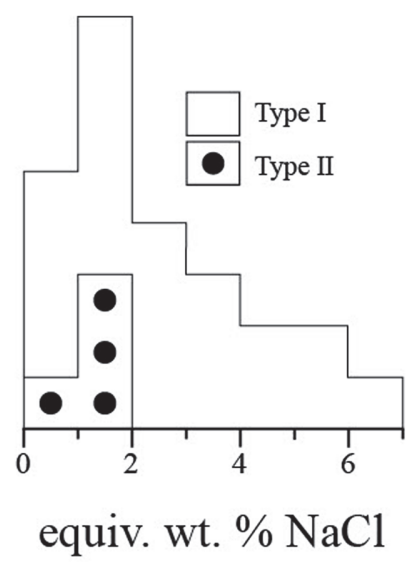

Fig. 7. Histogram of salinities of fluid inclusions in vein quartz of the Dongwon deposit. Abbreviations: Type I=type I fluid inclusion, Type II=type II fluid inclusion.

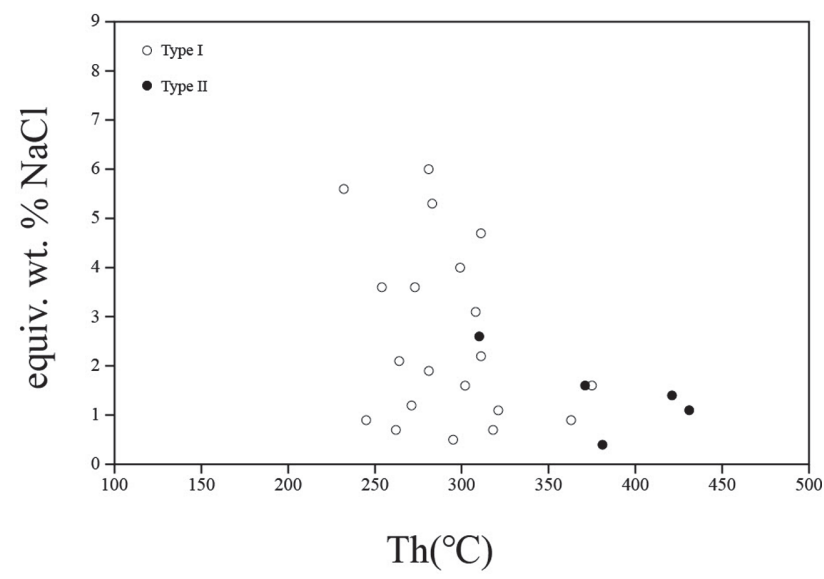

Fig. 8. Homogenization temperature versus salinity diagram for type I and II fluid inclusions in vein quartz of the Dongwon deposit. Abbreviations: Type I=type I fluid inclusion, Type II=type II fluid inclusion.

체포유물은 $431{ }^{\circ} \mathrm{C} ~ 371{ }^{\circ} \mathrm{C}$ 의 온도 범위에서 균일화된다 (Figure 6).

동원광상의 광화작용과 관련된 맥상 석영 내 유체포유
물은 6.0 0.4 wt. \% NaCl 상당 염농도를 보여준다. type I 초생 유체포유물(primary fluid inclusions)은 6.0 0.5 wt. $\% \mathrm{NaCl}$ 상당 염농도를, type II 초생 유체포유물(secondary fluid inclusions)은 약 1.6 0.4 wt. \% NaCl 상당 염농도 를 각각 보여준다(Figure 7).

\section{2. 동원 열수계의 열수유체의 진화특성}

동원광상 광화 1 시기 맥상 석영 시료의 유체포유물 균 일화온도는 비교적 넓은 온도범위 $\left(431^{\circ} \mathrm{C} \sim 232^{\circ} \mathrm{C}\right)$ 에서의 변화를 보여준다. 염농도의 경우 그 변화폭은 적으나 (6.0 0.4 equiv. wt \% NaCl) 열수유체의 진화 특성을 반 영하여 증감이 이루어진 것으로 확인된다.

Figure 8은 동원광상 유체포유물 가열·냉각실험 결과를 균일화온도와 염농도 상관도에 도시한 결과이다. 동원 함 금·은 열수광체의 균일화온도와 염농도 상관도에서 보는 바와 같이 동원 열수계에 유입된 초기 고온 $\left(\geq 431^{\circ} \mathrm{C}\right)$ 의 $\mathrm{H}_{2} \mathrm{O}-\mathrm{NaCl}$ 계 광화유체는 온도감소와 더불어 유체의 비등 (boiling)과 냉각 및 서로 다른 유체의 혼입(mixing) 등의 기구를 통하여 유체의 진화가 이뤼지며, 이러한 진화에 수반되는 물리·화학적 환경변화에 따라 서로 상이한 광 화작용이 진행되었을 것으로 해석된다. 동원광상의 함 금 ·은 열수 광화작용은 동원 열수계에 상대적으로 높은 온 도 $\left(\geq 431^{\circ} \mathrm{C}\right)$ 를 갖는 열수유체의 유입으로 광화작용이 시 작되어 약 $\geq 400^{\circ} \mathrm{C}$ 내지 $250^{\circ} \mathrm{C}$ 의 온도 범위에서 초기 열 수계 광화유체의 냉각 및 비등작용이 야기 되었다. 그 이 후 동원 열수계는 광화작용 후기의 광화작용을 야기한 유체 $\left(\leq 250^{\circ} \mathrm{C}, 3.0 \sim 0.0\right.$ equiv. wt. $\left.\% \mathrm{NaCl}\right)$ 의 혼입(fluidfluid mixing) 또는 천수 혼입(meteoric water mixing) 등에 의하여 진화되었으며, 이들 진화기구에 수반되는 냉각작 용과 화학성 변화에 의하여 온도 감소 $\left(\leq 250^{\circ} \mathrm{C}\right)$ 와 염농도 변화 $(\approx 0.4$ equiv. wt. $\% \mathrm{NaCl})$ 등이 야기되었다(Figure 8$)$. 상기 유체포유물 실험-연구 결과 확인된 동원 열수계 의 열수유체 진화과정을 통하여 규명된 동원 열수 맥상 광체의 금·은 및 수반 금속 광화작용은 다음과 같다. 동 원 열수계로부터 황철석, 자류철석 및 유비철석 등의 침 전이 야기된 초기 광화작용은 약 $\geq 430^{\circ} \mathrm{C} \sim 400^{\circ} \mathrm{C}$ 를 전후 한 온도 조건의 열수 유체로부터 냉각 및 초기 비등작용 에 의하여 진행되었다. 그 후 약 $370^{\circ} \mathrm{C}$ 온도조건을 전후 하여 야기된 동원 열수계의 계속된 비등작용에 의하여 열수의 온도감소 및 $\mathrm{H}_{2} \mathrm{O}$ 성분의 증발 등의 메커니즘에 의하여 광화작용 관련 성분들의 과포화가 야기되어 금의 침전을 비롯한 황동석, 섬아연석, 방연석 등의 주된 천금 속 황화광물과 황염광물 등의 광화작용이 진행되었다 (Figures 3 and 8). 그 후 동원 열수계에 유입된 상대적으 로 천부를 순환한 열수유체 또는 천수의 유입에 의하여 
냉각 및 희석작용이 진행되었으며, 그 결과 광화 1 시기 후기의 섬아연석, 방연석 등에 수반되어 함 은 광물인 휘 은석, 비소(As) 및 안티몬(Sb)계 황염광물 등 후기 광물 의 침전이 야기되었다.

\section{6. 광석광물의 지화학적 생성환경}

동원광상의 주 광화작용 시 광화유체 내의 환경변화를 규명하기 위하여, 광석광물의 산출 특성과 공생관계 및 유비철석, 섬아연석, 에렉트럼의 조성 특성, 유체포유물 실험·연구 결과 등을 활용한 열역학적 해석을 진행하였다.

동원광상에서 산출되는 유비철석은 대체로 황철석 및 자류철석과 공생하며 산출된다. 또한 섬아연석 또는 방 연석 내에 포유물로 산출되기도 한다. 따라서 유비철석 은 대체로 광화 초기에서 중기에 걸쳐 산출된 것으로 해 석된다. 동원광상에서 산출하는 유비철석의 $\mathrm{As}$ 함량을 Kretschmar and Scott(1976)이 제시한 Fe-As-S 계 T-X 다

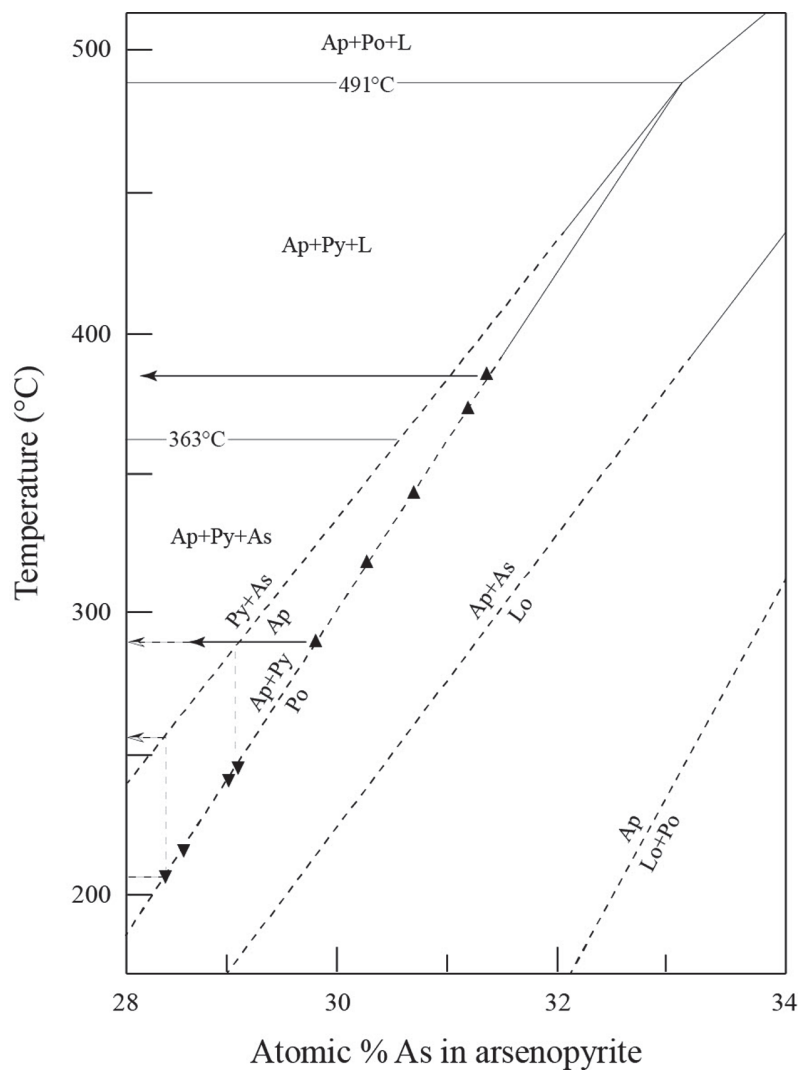

Fig. 9. Pseudo-binary condensed $\mathrm{T}-\mathrm{X}_{\mathrm{As}}$ section of the Fe-As-S system (Kretschmar and Scott, 1976). Filled triangles and inverted triangles indicate As contents in arsenopyrite, Dongwon deposit. Filled triangles (with pyrrhotite and pyrite) and inverted triangles (with pyrite and sphalerite) indicate As contents of arsenopyrite, Dongwon Au-Ag deposit. Abbreviations: Ap=arsenopyrite, Lo=loellingite, $\mathrm{Py}=$ pyrite, $\mathrm{Po}=$ pyrrhotite.
이어그램에 도시해보았다(Figure 9). 유비철석의 As 함량 과 광물 공생관계를 활용하여 유비철석 생성온도를 구해 보면, $\geq 380^{\circ} \mathrm{C} \sim 260^{\circ} \mathrm{C}$ 정도의 유비철석 정출 온도를 보 인다(Figure 9). 상기한 바와 같이 동원광상에서 산출되 는 유비철석은 산출상태 및 조직 등을 근거로 광화 초기 에서 중기에 산출되며, 이러한 유비철석의 정출온도는 광 화 초기의 말기 내지 광화 중기에 정출하는 에렉트럼의 정출 온도보다는 다소 높은 경향을 보인다.

동원광상 광화 1 시기의 각 광화시기에 대한 온도 및 황 분압(fugacity of sulfur( $\left(\mathrm{fS}_{2}\right)$ ) 조건의 범위 규명을 위하여 산출 광석광물의 상 관계 및 $\mathrm{Fe}-\mathrm{S}$ 계, $\mathrm{Fe}-\mathrm{Zn}-\mathrm{S}$ 계(Scott and Barnes, 1971), Au-Ag-S계(Barton and Toulmin, 1964: Craig and Barton, 1973)의 조성 변화를 활용하였으며, 그 결과는 Figure 10 에 제시되어 있다. 광화 1 시기 각 광화 시기의 온도 및 황 분압 조건의 변화는 광물 공생관계와 화학조성 변화를 반영하여 구분된 초기(early), 중기(middle), 후기(late)에 대하여 규명하였다(Figures 3 and 10).

동원광상 주 광화시기 초기에 산출하는 맥상 시료의 유 체포유물 균일화온도와 광물 공생관계, 황철석-자류철석 -유비철석(-자철석)의 광물 조합 및 초기에 산출하는 유 비철석 $(\leq 31.4$ atomic $\% \mathrm{As})$, 에렉트럼 $(\geq 27.3$ atomic $\%$ $\mathrm{Ag}$ ) 및 섬아연석의 화학조성(약 $0.9 \mathrm{~mole} \% \mathrm{FeS}$ ) 등을 활용한 초기 광화작용 시 온도 조건은 $\geq 380^{\circ} \mathrm{C}$ 에서 약 $320^{\circ} \mathrm{C}$ 이었으며, 황 분압 조건은 $\leq 10^{-6.0}$ 내지 $\geq 10^{-9.0} \mathrm{~atm}$ 이었다. 광화 1 시기 중-후기의 광물 조합(황철석-섬아연 석-방연석-에렉트럼, 황철석-섬아연석-방연석-휘은석) 및 에렉트럼(27.3 58.5 atomic \% Ag)과 섬아연석의 화학 조성(약 $1.0 \sim 8.5$ mole \% FeS)을 이용하여 규명된 온도

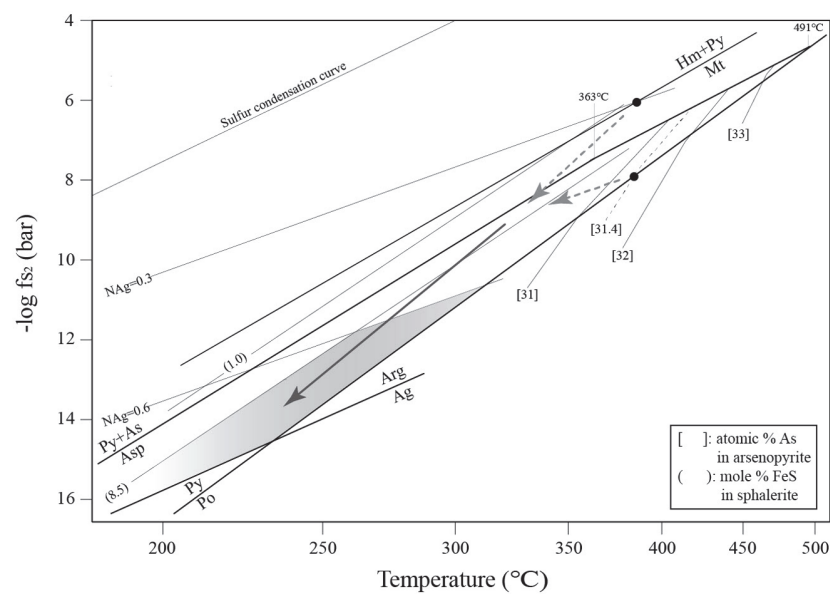

Fig. 10. Fugacity of Sulfur versus temperature diagram for stage I of Dongwon Au-Ag deposit showing the possible sulfur fugacity and temperature ranges with sulfidation reactions. Abbreviations: Arg=argentite, Asp=arsenopyrite, $\mathrm{Hm}=$ hematite, $\mathrm{Mt}=$ magnetite, $\mathrm{NAg}=$ atomic fraction $\mathrm{Ag}$ in electrum, $\mathrm{Po}=$ pyrrhotite, $\mathrm{Py}=$ pyrite . 
와 황 분압 조건은 각각 $\geq 330^{\circ} \mathrm{C} \sim \leq 200^{\circ} \mathrm{C}, \geq 10^{-9.5} \sim$ $\leq 10^{-16.0} \mathrm{~atm}$ 이었다. 휘은석의 산출로 특징지어지는 광화 1 시기 후기 광화작용의 온도 및 황 분압 조건의 하한은 $\mathrm{Ag}$-S계(휘은석/자연은)에 의하여 제한되어 각각 $\leq 200^{\circ} \mathrm{C}$, $\leq 10^{-16.0} \mathrm{~atm}$ 으로 확인되었다(Figure 10).

\section{7. 토 의}

전 세계적으로 함 금·은 광상을 포함한 함 금속 열수 맥상광상은 주요 금속광물의 침전 온도 및 광상의 생성 심도를 반영하여 심열수, 중열수 및 천열수 광상으로 분 류하고 있다.

Shelton 등(1988)은 상기 특성 등을 반영하여 국내 금. 은 광상들을 $\mathrm{Au} / \mathrm{Ag}$ 비, 황화광물들의 산출 특성, 금의 침 전 온도조건, 광상의 생성 심도, 모암 등의 특성을 반영 하여 중열수 광상, 한국형 광상 및 천열수 광상으로 분 류하였다.

또한 한반도 내 함 금·은 열수 맥상형 광상들은 금·은 생산량 비, 광석 중 금·은 함량비, 주 및 미량 원소들의 거동 특성, $\mathrm{Fe}-\mathrm{S}$ 계 광물 및 $\mathrm{Ag}$ 계 광물들의 산출 특성, 산출 광물의 공생관계와 광물학적 특성, 열수 맥의 조직적 특성 등 산상 및 모암 특성과 생성시기 등을 반영하여, 금 단 일형 광상인 Group I(자류철석형 금광상)과 Groups IIA, $\mathrm{IIB}$ (황철석형 금광상), 금-은 혼합형광상인 Group III(휘 은석형 금은광상)와 Group IV(안티몬형 금은광상), 은 단 일형 광상인 Group V(안티몬형 은광상)의 6가지 유형으 로 분류되며, 동일한 유형인 열수 맥상광상에서도 성인 적 차이점이 도출된 바 있다(최상훈, 2000; 최선규 등, 1988a, b).

동원광상은 열수 광화작용에 의하여 생성된 괴상 및 각 력상 조직과 함께 정동의 발달 등 복합적인 조직적 특성 을 보여주는 함 금·은 석영 맥상 광체이다. 동원광상의 광화작용은 지구조적 운동(tectonic break)에 의하여 광화 1 시기(stage I)와 광화 2시기(stage II)로 구분된다. 광화 1 시기는 함 금-은 열수 광화작용이 석영맥의 생성과 함께 진행된 주 광화시기로서, 열수 석영맥 내 주된 함 금·은 광물인 에렉트럼(electrum)과 함께 함 금속 황화광물, 산 화광물 및 황염광물 등이 산출한다. 광화 2 시기는 주 광 화작용 이후의 함 금-은 등 금속 광화작용이 이루어지지 않은 방해석과 백운석맥의 생성 시기이다. 동원 열수계 는, 유체포유물 실험·연구 결과, $\mathrm{H}_{2} \mathrm{O}-\mathrm{NaCl}$ 계로 확인되었 다. 동원 열수계로부터 황철석, 자류철석 및 유비철석 등 의 침전이 야기된 초기 광화작용은 약 $\geq 430^{\circ} \mathrm{C} \sim 400^{\circ} \mathrm{C}$ 를 전후한 온도 조건의 열수 유체로부터 냉각 및 초기 비등 작용에 의하여 진행되었다. 그 후 약 $370^{\circ} \mathrm{C}$ 온도조건을
전후하여 야기된 동원 열수계의 계속된 비등작용에 의하 여 열수의 온도 감소 및 $\mathrm{H}_{2} \mathrm{O}$ 성분의 증발 등의 메커니 즘에 의하여 광화작용 관련 성분들의 과포화가 야기되어 금·은의 침전을 비롯한 황동석, 섬아연석, 방연석 등의 주 된 천금속 황화광물과 황염광물 등의 광화작용이 진행되 었다. 그 후 동원 열수계에 유입된 상대적으로 천부를 순 환한 열수유체 또는 천수의 유입에 의하여 냉각 및 희석 작용이 진행되었으며, 그 결과 광화 1 시기 후기의 천금 속 황화광물에 수반되어 함 은 광물인 휘은석, 비소(As) 및 안티몬(Sb)계 황염광물 등 후기 광물의 침전이 야기 되었다.

동원광상에 대한 지화학적 환경변화 결과(Figure 10)를 최선규 등(1988a, b, 1992, 1993, 1994)에 의하여 제시된 금 단일형(Au-dominant type) 광상, 금-은 혼합형 $(\mathrm{Au}-\mathrm{Ag}$ type) 광상 및 은 단일형(Ag-dominant type) 광상 각각에 대한 지화학적 환경변화와 비교하면, 동원광상은 광화 1 시기 초기는 금 단일형 광상 또는 금-은 혼합형 광상의 지화학적 환경변화 특성과 대비되며, 광화 1 시기 중·후기 는 금-은 혼합형 광상의 지화학적 환경변화 특성과 대비 된다. 동원광상의 열수계 광화유체의 진화 특성과 온도 및 염농도 변화 경향성은 금-은 혼합형(Group III and Group IV)에 해당하는 광상들과 대비된다. 동원광상의 광 물학적, 열역학적 및 유체포유물 연구 결과를 Shelton 등 (1988)이 제시한 국내 금·은 광상들에 대한 분류 기준에 비교할 경우, 동원광상은 한국형 금·은 광상들에 대비된다.

이상의 연구 결과를 종합하면, 동원광상은 한국형 금. 은 광상 및 Group III에 해당하는 중/천열수 광상에 대비된다.

\section{사 사}

이 논문은 2021학년도 충북대학교 연구년제 지원에 의 하여 연구되었음. 이와 함께 한국광물자원공사의 2020년 정밀조사 학술연구용역의 지원을 받아 수행되었다. 현장 광상 조사 시에 함께하여 도움을 주신 한국광물자원공사 탐사팀 팀원들에게 감사의 마음을 전합니다. 본 논문을 세심하게 검토하여 고견을 주신 익명의 심사자들께 진심 으로 감사드린다.

\section{References}

대한지질학회 (1999) 한국의 지질. 시그마프레스. 802p. 박희인, 박영록 (1990) 동원광산의 금-은 광화작용. 광산지질, v.23, p.183-199.

손치무, 정창희 (1965) 태백산지구의 퇴적환경과 지질구조. 서 울대학교 논문집 이공계, v.15, p.1-27.

최상훈 (2000) 국내 금·은광상 성인별 모델링연구. 대한광업진 
흥공사, 광진 2000-2, 119p.

최선규 (1993) 한국 중부 지역 금-은 광상산 섬아연석의 조성 변화와 성인적 특성. 광산지질, v.26, p.135-144.

최선규, 박노영, 홍세선 (1988a) 충청도 일원의 금-은 광상에 대한 광물학적 연구. 광산지질, v.21, p.223-234.

최선규, 박맹언, 최상훈 (1994) 한국 동남부 지역 금-은 광상 산 에랙트럼의 화학조성. 자원환경지질, v.27, p.325-333.

최선규, 위수민 (1992) 에랙트럼의 화학조성과 관련된 한국 중 부 금-은 광상의 성인적 특성. 지질학회지, v.28, p.196-219.

최선규, 지세정, 박성원 (1988b) 충청북도 영동지역 금-은 광상 의 광화작용에 관한 연구. 광산지질, v.21, p.367-380.

최선규, 최상훈 (1995) 한국중부와 동남부지역 금·은 광화작용 의 성인적 특성. 자원환경지질, v.28, p.587-597.

한국광물자원공사 (2020) 호명지구(금·은) 정밀조사 보고서(호 명 111, 호명 112호), 106p.

한국지질자원연구원(KIGAM) (1962a) 예미도폭 $(1: 50,000)$.

한국지질자원연구원(KIGAM) (1962b) 임계도폭 $(1: 50,000)$.

한국지질자원연구원(KIGAM) (1962c) 정선도폭 $(1: 50,000)$.

한국지질자원연구원(KIGAM) (1962d) 호명도폭 $(1: 50,000)$.

Barton, P.B., Jr. and Toulmin, P., III. (1964) The electrum-tarnish method for the determination of the fugacity of sulfur in laboratory sulfide system. Geochim. Cosmochim. Acta, v.28, p.619-640. doi: 10.1016/0016-7037(64)90082-1

Craig, J.R. and Barton, P.B. Jr. (1973) Thermochemical approximations for sulfosalts. Econ. Geol. v.68, p.493-506. doi: 10.2113/ gsecongeo.68.4.493

Haynes, F.M. (1985) Determination of fluid inclusion compositions by sequential freezing. Econ. Geol., v.80, p.1436-1439. doi: 10.2113/gsecongeo.80.5.1436

Kretschmar, U. and Scott, S.D. (1976) Phase relations involving arsenopyrite in the system Fe-As-S and their application. Can. Miner., v.14, p.364-386.

Potter, R.W. III, Clunne, M.A. and Brown, D.L. (1978) Freezing point depression aqueous sodium sodium chloride solutions. Econ. Geol., v.73, p.284-285. doi: 10.2113/gsecongeo.73.2.284

Scott, S.D. and Barnes, H.L. (1971) Sphalerite geothermometry and geobarometry. Econ. Geol., v.66, p.653-669. doi: 10.2113/ gsecongeo.66.4.653

Shelton, K.L., So, C.S. and Chang, J.S. (1988) Gold-rich mesothermal vein deposits of the republic of Korea: Geochemical studies of the Jungwon gold area. Econ. Geol., v.83, p.1221-1237. doi: 10.2113/gsecongeo.83.6.1221 